\title{
The ambiguity of khat in Somaliland
}

\author{
Peter Hansen* \\ Danish Institute for International Studies, Migration, Strandgade 56, 1401 Copenhagen, Denmark
}

\section{A R T I C L E I N F O}

\section{Article history:}

Received 4 October 2009

Received in revised form 22 January 2010

Accepted 4 February 2010

Available online 6 March 2010

\section{Keywords:}

Catha edulis

Somaliland

Societal effects

Regulation

Development

\begin{abstract}
A B S T R A C T
Aim of the study: This article presents an analysis of the economic, political and socio-cultural significance of khat in Somaliland, highlighting both its positive and negative effects.

Materials and methods: Thirteen months of anthropological fieldwork in Somaliland, two months of anthropological fieldwork among Somalis in London, four months experience from the Somalia Joint Needs Assessment working as a development specialist on khat, as well as available and relevant literature.

Results: The recent growth in khat consumption in Somaliland is linked to dispersal, unemployment, socio-cultural changes caused by the civil war, and the massive inflow of remittances. Consumption takes place because of an encouraging socio-cultural environment, few opportunities for education and employment, lack of care and support from parents, as well as widespread availability. Khat represents a significant economic drain on the Somaliland economy, but is also an important source of income for the state and an employment opportunity for thousands. The consumption of khat among government employees challenges the efficiency of state institutions, but also provides a participatory and peaceful political environment that is vital to the democratic transformation of Somaliland. Khat causes the breakdown of families and seriously challenges Somali socio-cultural identities, values and practices. However, khat also strengthens male networks, communities and senses of belonging to Somaliland.

Conclusion: The article argues that khat has both negative and positive effects on Somaliland society. Comparing the role of khat in Somaliland with khat in Puntland and South-central Somalia it is clear that khat in itself does not determine if it contributes to state building and peace, or state failure and violence. Rather, it is the socio-cultural, political and historical context in which it is consumed that determines its larger societal effects. A nuanced analysis of the positive and negative aspects of khat that builds on local perceptions and practices is necessary in order to work with khat from a regulatory and developmental perspective.
\end{abstract}

(c) 2010 Elsevier Ireland Ltd. All rights reserved.

\section{Introduction}

This article examines khat (Catha edulis) in Somaliland. Since its declaration of independence in 1991, Somaliland has undergone a remarkable political transformation. The political leadership and clan elders have reconciled former warring clans, created a bicameral political system and carried out local, parliamentarian and presidential elections (Bradbury et al., 2003; Renders, 2007; Hoehne, 2009). Somaliland also has its own flag, national anthem, currency, police force, army and coast guard which makes it different from other parts of Somalia that continue to be characterized by failed or weak government institutions, piracy and militant Islamic movements (Lewis, 2002; Bradbury, 2008). Apart from its vitality as a political entity, Somaliland also has a thriving private sector with the existence of thousands of small shops, large import-export companies and international communications and transport companies (Little, 2003; Hansen, 2004). Despite its political achievements and popular support, Somaliland is not internationally recognized as an independent nation-state and should therefore be considered a de facto state (Hoehne, 2006; Hagmann and Hoehne, 2009).

One of the most visible signs of the existence of a vibrant private sector, and indeed one of the most striking features of contemporary Somaliland society, is the trade in and consumption of khat (cf. Bradbury, 2008:153). Much like alcohol in most western societies, khat plays a crucial role in the social life of most Somali men (cf. Green, 1999:42). Being in Hargeisa, the capital of Somaliland, one quickly learns that khat is important. Before lunch and the arrival of fresh Ethiopian khat at around $11 \mathrm{am}$, most men are busy sorting out with whom and where to chew later in the afternoon. After lunch, the better off consumers usually meet in private homes, whereas poorer consumers go to one of the public khat cafés or mafreshes that are found in any larger town or village, and where khat and tea are usually provided by a female khat vendor. ${ }^{1}$

\footnotetext{
* Tel.: +45 32698706 .

E-mail address: pha@diis.dk.
}

1 The mafresh is also sometimes referred to as majlis, or in south Somalia as cabar. 
With khat playing a crucial role in society, whether one chews or not, or more likely, to what extent, with whom, where and what kind of khat one chews, are all important elements in defining male identities, social networks, work careers and personal values.

Within the past two decades the consumption of khat has increased dramatically. Before the war, khat was mostly chewed on Thursdays or Fridays, in connection with particular rituals such as weddings, funerals, religious gatherings or readings (e.g. maulids), and on occasions when it was essential to stay awake, such as during truck driving or preparing for exams. Because of the war, the socio-cultural norms that used to regulate the consumption of khat no longer exist, or at least they have been radically challenged, with the large majority of the male population chewing khat every day. The change in khat consumption is seen, not only in an overall increase, but also in the consumption of yesterday's khat (berixi), in the consumption of khat outside private homes, in the consumption of khat by an increasing number of adolescents, women and nomads, and in the consumption of khat before lunch. ${ }^{2}$ The consumption of khat is so widespread that it affects the economic and political life of Somaliland, the lives of most individuals and families, and socio-cultural values, practices and identities.

Both in- and outside Somaliland, khat is a hot topic with nonchewers typically critiquing and chewers defending it (cf. Anderson and Carrier, 2006; Anderson et al., 2007). Critics see it as the most serious challenge to the further development of Somaliland, whereas consumers most often see it as a Somali tradition that has both positive and negative aspects. The critique of khat is most strongly presented by women's organizations and female politicians who argue that khat destroys Somali men and leads to the neglect of children and domestic violence; the international development community who argues that khat presents a severe drain on the economy and hampers the formation of an efficient bureaucracy; Islamic leaders influenced by Wahabi interpretations of the Quran who argue that khat is haram; members of the diaspora who are appalled when remittances intended for food and education are used for khat; as well as by some of the largest private sector employers who argue that it has a negative effect on the workforce. Most politicians in Somaliland are heavy consumers of khat and believe that it is a problem that needs to be dealt with. However, it is rarely their consumption, but rather that of others, that is, the women, the poor and the youth that is problematic and needs regulation.

In this article I examine how khat affects contemporary Somaliland society as an economic, political and socio-cultural entity. Rather than seeing khat merely as synonymous with state failure and as an obstacle to development and economic progress, the article presents a more nuanced analysis building primarily on local perceptions and practices relating to khat. The basic argument of the article is that the ways in which khat currently affects contemporary Somaliland society is ambivalent in the sense of both "polluting the nation" and being a "flower of paradise" (Anderson and Carrier, 2006).

The article begins by examining the growth in khat consumption that has taken place within the past decades and by presenting an analysis of why people continue to consume khat. It is highlighted that an increase in khat consumption is linked to dispersal, increased unemployment and the social and cultural

\footnotetext{
2 Khat consumed in the morning is referred to as jabane, deriving from the Oromo word igabana which literally means 'eye-opener' (Gebissa, 2004:8) and which connotes that you chase the khat hangovers (khadiro) from yesterday's chewing session away. Chewing in the afternoon is referred to as barje which simply means to chew, whereas chewing in the evening is referred to as isqarxis, connoting that you commit suicide. Consumers of khat often proudly argue that jabane needs to be shared with anyone wishing a twig or two, and as such that they are particularly social and giving.
}

changes caused by the civil war and state failure in Somalia. The article then examines khat as a traded good that represents a severe drain on the economy of Somaliland and individual households. On the positive side, it is highlighted that khat has also become an important source of revenue for the state and represents an important employment opportunity, especially for thousands of women. Apart from its economic significance, the article also examines the political significance of khat. Rather than representing a mere challenge to the ongoing process of democratisation, the article argues that khat has been and continues to be important to the relative political success of Somaliland as it fosters the creation of a peaceful and participatory political environment. The article then discusses how khat both underpins and challenges socio-cultural identities and values. In particular, the article examines the ways in which khat challenges traditional gender categories. In conclusion, the article compares khat in Somaliland with khat in other parts of Somalia and presents recommendations for policy makers in terms of regulating and working with khat as an obstacle to development.

\section{Methods}

\subsection{Chewing khat as participant observation}

The article is based on thirteen months of fieldwork in Somaliland taking place in a period from 1998 to 2006. An additional two months of fieldwork was undertaken among Somalis in London in 2003. Moreover, the article draws on my continuous engagement with Somali men living in Denmark who often consume and have strong opinions about khat (cf. Ahmed, 2005; Klein, 2004, 2007). One of the key methods of anthropological fieldwork is participant observation whereby the researcher takes part in the daily activities, rituals, interactions and events of a group of people as a means of gaining inside knowledge on local practices and values (DeWalt and DeWalt, 2002:1). During my fieldworks in Somaliland, emphasis has been on the return of the western diaspora and not on khat as such (Hansen, 2004, 2007a,b, 2008). However, chewing khat with the local population quickly became an important methodology for doing fieldwork, as it provided a way for me to participate in society and to gain a local perspective on various aspects of Somaliland society. Often, after the completion of an interview, I have been told that if I really wanted to know someone, I would need to sit down and chew khat with that person. In this sense, khat has provided an entry point into peoples lives, as the experience of chewing together builds trust and interpersonal relations. When chewing khat in Somaliland, I have often been treated as an apprentice and therefore been provided with valuable information about the practices, effects and vocabulary relating to khat. Moreover, as the large majority of the male population chews khat every afternoon, chewing khat was often necessary in order to get to know people, access key informants and to take care of practical matters such as finding a place to live, employing local research assistants, etc.

One of the challenges of participant observation is for the researcher to uphold a balance between participation and observation-between on the one hand establishing close contact with the people being studied, and on the other to remain an outsider capable of making disinterested observations and analysis (Davies, 1999:70-72). As diasporic returnees tend not to chew as much as the local population, I would only chew khat once or twice a week whereby this balance was upheld. My status as a part-time chewer enabled me to understand both consumers and non-consumers who tend to be rather antagonistic towards each other. In overall, through participant observation and interviews made with consumers and non-consumers, I have generated data on ideas, norms and interpretations, as well as practices relating to khat (cf. Holy and Stuchlik, 1983). 


\subsection{Working with khat as a developmental problem}

The article is also based on my experiences as a khat consultant working for four months for the United Nations Development Programme during the Somalia Joint Needs Assessment that took place in 2005 and 2006, where I had the opportunity to discuss and chew khat with a range of individuals, organizations, politicians, bureaucrats, traders and consumers in Somaliland, Puntland ${ }^{3}$ and South-central Somalia. Apart from conducting formal interviews about khat with key informants, participating in chewing sessions often developed into group interviews where consumers would debate various issues relating to khat. Moreover, the article draws on observations made from visits made to khat markets and retailers in Somaliland, Puntland and South-central Somalia. Finally, during my time as a khat consultant, I participated in workshops in South-central Somalia (Jowhar) and Somaliland (Hargeisa) where various local and international stakeholders were present and where khat was debated. It should be stressed that this article presents the role of khat as seen from a local perspective and that it does not offer a pharmaceutical or medical analysis of khat, nor does it present data on consumption patterns at macro-level.

\section{Results}

\subsection{The growth in khat consumption}

There is no agreement on when and how khat initially entered Somaliland society. According to Gebissa (2004:11) khat has been an institutionalized part of the religious life and practices of the Muslim population of eastern Ethiopia since the 14th century. The use of khat by Somalis probably spread from Ethiopian to Somali Muslim communities several hundreds of years ago (Cabdi, 2005:295). In the beginning of the 20th century, chewing khat was mostly restricted to religious groups, but in the 1920s, 1930s and 1940s, consumption increased as a result of infrastructural developments linking the khat producing Ethiopian highlands with emerging markets in Somaliland, the process of urbanization, and the formation of an urban class with enough time and money to chew khat. With the union between British and Italian Somaliland in 1960 and the migration of thousands of northerners to the capital of Mogadishu, the practice of chewing khat was introduced to the southern parts of Somalia (Cassanelli, 1986; Elmi, 1983; Warsame, 2004). The legacy of khat spreading from the north to the south is seen in contemporary khat terminology used all over Somalia that is based on the northern Somali dialect. Moreover, people from the north and in particular from Hargeisa are renowned for their use of khat in most parts of Somalia.

In the 1960s local farmers belonging to the Isaq clan living in the north-western part of Somalia started to grown khat in order to cope with droughts and poverty (Samatar, 1989:138-147). The success of these early khat farmers inspired other farmers in the area to also grow khat, and by the late 1970s, khat had become an important local cash crop with khat farmers being referred to as the "khat elite" (Samatar, 1985:50). With the defeat against Ethiopia in 1978 , the Somali government increasingly relied on the support of one clan, the Darood, with the result of marginalising other clans and in particular the Isaq that were among the first to oppose the government (Lewis, 1994:177-220). In an effort to weaken and marginalise the Isaq, the government banned khat in 1983. The government legitimated the ban by arguing that khat was a serious

\footnotetext{
${ }^{3}$ Similar to Somaliland, Puntland has its own government and state institutions. However, rather than seeking independence as a separate nation-state, Puntland has opted for autonomy within a future federal Somalia (Doornbos, 2002; Hoehne, 2006, 2009).
}

health problem, a severe drain on the economy of the nation and households, caused social problems, killed creativity, reduced the efficiency of the workforce and led to laziness, apathy, theft, robbery, corruption, poverty and tribalism (WHO, 1983). Similar to the criticism being raised today, khat was presented as posing an obstacle to the development of the Somali nation-state. In the name of development, the khat ban was coupled with an eradication campaign where local khat fields were destroyed. However, from the perspective of the Isaq, the ban and eradication campaign were seen as acts of state violence and linked to the repression of the north by the regime based in Mogadishu (Samatar, 1989:160; Bestemann, 1999:16; Green, 1999:37; Cabdi, 2005:296). One of the effects of the khat ban was increasing support for the Somali National Movement (SNM) that was defending the interests of the Isaq. According to my informants, the ban and eradication campaign put an effective stop to any local production of khat, but rather than lowering consumption, they only transferred the khat trade from the hands of the Isaq to the Gadabursi in western Somaliland that were allies of Siad Barre, and to state and army officials that smuggled khat across the Ethiopian-Somali border (cf. Samatar, 1985:55-56). ${ }^{4}$ When the SNM initiated its offensive in 1988, it was not only an attack on government forces, but also a strategy intended to bring back the control over the khat trade between Ethiopia, Djibouti and Somalia (Simons, 1995:76). As such, khat should be seen as being linked to the civil war and the collapse of the Somali state.

The government responded to the SNM offensive by bombing the northern towns of Hargeisa and Burao, causing hundreds of thousands of refugees to flee across the border to Ethiopia. One of the results of the dispersal of the Somalis into eastern Ethiopia was an increase in the consumption of khat among the male refugee population. Many male camp refugees simply picked up the habit of chewing local Ethiopian khat as a way of coping with the traumas and frustrations caused by the civil war. The practice of chewing outside the home, a practice that is common in Somaliland today, was adopted in Ethiopian refugee camps. According to my informants they often felt guilty for not being able to defend and provide for their families and therefore sought refuge in khat. Moreover, some felt guilty for not joining the SNM and picking up arms against Siad Barre. The growing demand for khat in the refugee camps was largely met by industrious Somalilanders. Many of the importers, wholesalers and retailers of khat found in Somaliland today, started their business in the refugee camps, as did large parts of the private sector. The global dispersal of Somalis also caused an increase in khat consumption both at home and abroad. First of all, the first generation of male Somali refugees picked up khat as a way of coping with frustrations and preserving Somali cultural identities (Ahmed, 2005; Klein, 2007). Secondly, the consumption of khat in Somaliland increased as a result of the massive inflow of remittances (Hansen, 2004; Lindley, 2006). ${ }^{5}$

\subsection{Why people chew}

Today, khat is consumed for a variety of reasons including lack of care and support from parents, an encouraging cultural environment, few opportunities for education and employment, a lot of free and unstructured time without constructive and challenging social alternatives, as well as widespread availability. Critics often stress that khat is a drug, and that consumers are drug addicts. Conversely,

\footnotetext{
4 The local production of khat that took place in the Gebiley area west of Hargeisa has not been fully re-established since the eradication campaign in 1983 and today only supplies relatively few local consumers. Locally grown khat is considered inferior to Ethiopian khat, which is grown in the proper altitudes and therefore is more potent (cf. Cabdi, 2005: 296)

5 See Weir (1985) for an analysis of how an increase in khat consumption in Yemen in the 1970s and 1980s was also caused by the massive inflow of remittances.
} 
chewers argue that khat is not a drug, that they are not addicted, and that it has only spread because of other circumstantial factors such as the lack of employment opportunities and alternatives. To support the classification of khat, not primarily as a drug but as a social activity, consumers often highlight that whereas there are words and expressions describing someone that chews extensively (marqan weyne), chews too much (qaadwale), admires khat (qaad qabax) and is very picky about his khat (yabaal), there are no words or expressions describing someone that is addicted to khat. Moreover, consumers often highlight that they are able to give up khat quite easily, for example during Ramadan, or when they migrate to a place where it is not as readily available and affordable. Consumers also argue that once they quit khat, they only suffer mild withdrawal symptoms, which often come in the form of nightmares known as dubaab, slight trembling and tiredness (cf. Cox and Rampes, 2003:459; Dhaifalah and Santavy, 2004:13; Odenwald et al., 2009). ${ }^{6}$

If admitting to any kind of addiction, chewers argue that they are addicted to the social company and comfort existing in the chewing session, rather than to khat as a drug. Moreover, if admitting to any kind of abuse, consumers argue that it occurs when chewing leads to the neglect of children or in other ways has negative effects on other people. Also, the majority of consumers argue that abuse takes place if chewing takes place both before and after lunch, and as such outside the usual afternoon chewing session. However, in the eyes of most consumers, simply chewing khat for a few hours in the afternoon in the company of good friends does not in itself constitute abuse. To stop chewing khat one would not only suffer the minor physical withdrawal symptoms but also, and more importantly, miss out of the companionship, friendship, information and social networks that are part of chewing practices. As such, from the perspective of consumers, the most severe withdrawal symptoms should be understood as socially defined, that is as the experience of being deprived of social networks and companionship (cf. Kennedy, 1987:209).

It is a widespread belief among consumers of khat that it has spread because of unemployment and that an increase in employment opportunities will automatically lead to its decline. There surely is some validity in this argument, as there are very few employment opportunities in contemporary Somaliland society. Contributing to the positive correlation between khat and unemployment is the practice for many unemployed men to try to secure a job by strengthening their social networks through the khat session. To the unemployed, the chewing session is often crucial in terms of establishing the right social connections and to access information about available jobs. During a chewing session a lot of useful information is exchanged, and they are referred to as "oral newsletter" supplying valuable information about any given subject.

In this sense, chewing khat is not a hindrance for finding employment, but can be seen as a rational way of optimizing networks, accessing information and ultimately of securing a livelihood. The notion that khat, work and livelihoods are not incompatible is also reflected in the fact that many consumers see khat as necessary in order for them to perform in a work situation. For example, private business people are known to make important business deals while chewing khat, and employees of the numerous NGOs also chew khat in order to discuss problems and to come up with new ideas for development programs. Also, people holding jobs where reflec-

\footnotetext{
${ }^{6}$ Chewers often tell stories of nightmares emerging once they quit khat. One particular kind of nightmare, in which the individual is possessed by a cat entering their body through anus, is particularly widespread among consumers. The symbolic meaning of this particular nightmare and any possible connection to popular Somali folktales is unknown to the author.
}

tion and analysis are needed often argue that khat enables them to think more clearly and to come up with new perspectives on any given issue. Often I have been told by chewers, that in order to finish my PhD, I would need to chew khat, as it would boost my energy levels and help me understand my research questions more clearly. Similarly, manual labourers often argue that khat enables them to work hard, as it gives them energy. However, the notion that khat and work are inseparable, or at least not incompatible, seems to be changing, as the most successful private companies insist on a no-chewing policy. For example, the largest remittance company, Dahabshiil, only hires non-chewers, and is also open for business in the afternoon, something that is quite uncommon as it prevents employees from participating in afternoon chewing sessions.

Khat is also consumed simply because it is so widespread and normal. With sheiks, elders, governors, mayors, ministers, intellectuals, doctors, students, teachers, fathers, brothers and almost everyone else chewing khat, one needs to be an ardent non-chewer in order not to chew khat. Khat and the chewing session is simply where the social action is, as most other forms of entertainment, be they theatres, cinemas or libraries have disappeared as a result of the civil war. Moreover, contrary to South-central Somalia where hashish and alcohol are more readily available, khat is what you get in Somaliland. The lack of social alternatives to khat is partly caused by the influence of conservative religious leaders who oppose the existence of nightclubs, or even youth clubs, and instead offer more strict interpretations of the Quran. Moreover, in Hargeisa, owners of restaurants and cafés that are popular among the youth, as they provide an opportunity to play pool, drink coca cola and listen to western music, are often harassed by the police for violating Somali cultural norms and Islamic values. Before the war, schools and institutes of higher learning were open both before and after lunch. Today, only private and Islamic schools are open in the afternoon which means that thousands of young people have nothing to do in the afternoon. Rather than going to a real university, Somaliland youth explain that they instead sign up for "khat university". As chewing khat is a norm, it follows that many also start chewing because of peer pressure. Some consumers only attend chewing sessions to have a social life and are often not particularly fond of khat. However, as almost everything in society works through social networks, chewing khat is often a necessary livelihood strategy. Non-consumers often find themselves somewhat socially isolated and will have to rely on other strategies, often by prioritising formal education and religious networks and identities.

Whereas the consumption of khat was most likely introduced to present day Somaliland by Oromo Muslims from eastern Ethiopia (Gebissa, 2004), today there are very few consumers of khat who argue that they chew for religious purposes. The link between khat and Sufism is most clearly seen further east in neighbouring Puntland where chewers occasionally explain that they chew in order to feed their spiritual souls (rux), and that they are able to sometimes see the name of Allah on khat leaves. In Somaliland, the link between Islam and khat is mostly reflected in marketing strategies applied by various khat importers. For example, the main importer brands his khat under the name of 571, which refers to the year the prophet Mohammed was born (cf. Anderson et al., 2007:59). Similarly, another khat brand, now out-competed during a price war with the 571 brand, was marketed under the name of B611, which refers to the year when the prophet Mohammed received his first revelation. ${ }^{7}$ When khat importers such as the 571 and

\footnotetext{
7 The prefix "B" stands for barako, meaning blessing received from Allah. The price war took place in 2004, went on for 10 months and related to the control of the khat market in central Somaliland. According to informants, during the price war, daily imports to Burao increased from approximately $7000 \mathrm{~kg}$ to $12000 \mathrm{~kg}$. The B611 brand lost the price war and eventually left the khat business altogether facing a loss of
} 
B611 brands compete for market shares, the price of khat is lowered substantially enabling a larger number of poorer consumers to buy cheap khat. Moreover, the fact that the price of khat falls during the day has surely enabled poorer and young consumers to develop a habit of chewing khat. In this sense, the recent growth in khat consumption reflects the existence of an unregulated market.

\subsection{Khat as a business}

The khat market in Hargeisa is known as one of the most extensive khat markets in all of East Africa where you get a wide variety of khat types catering for both rich and poor consumers. The most widely consumed khat is dardar that can be purchased at around US\$6 to US\$7 per bundle or marduf. ${ }^{8}$ Among chewers, dardar is considered clean as it is known to be produced without the use of chemicals and pesticides. The more expensive and potent types of khat, such as chepes, fugis and damarmusbar, usually cost around US\$ 15 to US\$ 20 per kilo and is often the choice of politicians and high ranking government officials. ${ }^{9}$ The cheaper kinds of khat, such as tajaaro, bandaro, garabo and kurus usually cost around US\$ 0.5 to US\$ 1.5 per bundle, but are less potent and often give more severe khat hangovers. Due to the cost of transport the price of khat approximately doubles from Hargeisa to the eastern parts of Somaliland and western parts of Puntland that are supplied with Ethiopian khat via Somaliland. The price also varies with the season, as khat in the dry period is more expensive than in the rainy season. The khat market is one of the noisiest and busiest places in town with wholesalers and retailers competing for customers, often with the use of handheld megaphones. Apart from the central market, khat can also be purchased from one of the numerous smaller stalls found all over town.

What is often highlighted by critics of khat is that it has a negative effect on the overall economy of the country, as it lowers the efficiency of the workforce, leads to passivity and thereby challenges the renowned Somali entrepreneurship. Moreover, it drains the economy as almost all khat consumed in Somaliland is imported from Ethiopia. It is difficult to say exactly how much khat is imported from Ethiopia, but based on figures provided by customs officials in Hargeisa and interviews with khat importers, it is my estimate that around 6.500 and $7.200 \mathrm{t}$ is imported every year, which represent a value of around US\$ 50 million. Considering that the annual budget for Somaliland is around US\$ 50 million this is a considerable figure. Critics argue that money spent on khat only benefits the Ethiopians and that it could be used more productively, for example by investing in the private sector or by taking better care of the wellbeing of children and their education. However, with the khat trade across the Ethiopian-Somaliland border being partly in the control of the Isaq, it has to be stressed that some of the funds spent on khat imports remain within Somaliland families and as such do not leave the Somaliland economy. For example, the 571 khat business is essentially based on the marriage between two Isaq, with the wife (Suhuura Ismail Kehim) living in Jigjiga in Ethiopia and the husband (Ina Afdinle) in Hargeisa. The wife is responsible for the supply side and the husband for distributing and selling khat in Somaliland and Puntland. The overall effectiveness of the khat trade network partly rests on such alliances between

\footnotetext{
US\$ 600.000 .

8 These prices, as well as other prices on khat mentioned in this section, were collected at the khat market in Hargeisa, January 2006 (exchange rate: 1 US $\$=5.500$ Somaliland Shilling). The cheaper kinds of khat are usually paid for in Somaliland Shilling, whereas the more expensive types of khat are usually paid for in US\$.

9 The quantification of dardar relies on its own terminology: a bundle is called mijin and four mijins make up one bundle or marduf. The more expensive khat types are measured in the metric system: $1 / 4$ kilo is known as rubux, $1 / 2$ a kilo as nus or kisif kilo and 3/4 kilo as falad.
}

clan or sub-clan members which secure trust between exporters, importers, drivers, porters and wholesalers (cf. Little, 2003). The 571 khat brand is a large employer in Somaliland and known to have an important influence on policy making. Lately, the 571 brand expanded its business to also include an airline ("Suhuura Airways") that will fly between Addis Ababa and Hargeisa, a market left vacant by the decision by Ethiopian Airline to pull out of Somaliland following suicide bombings in Hargeisa in October 2008 (Somaliland Times, 2009).

Apart from representing a drain on the economy, the taxation of khat imports provides an important source of capital for the Somaliland government (cf. Hagmann and Hoehne, 2009:49; Green, 1999:39). According to customs officials in Hargeisa, the government collected around US\$ 5.5 million in khat import taxes in 2005 which means that khat revenues account for $10 \%$ of the country's budget. The local municipalities all over the country also collect taxes from retailers and wholesalers. However, the local taxation of khat traders is quite low and most often only plays a minor role in the economy of municipalities. Apart from the fact that khat revenues are crucial for the economy of the Somaliland state, khat is also an asset in terms of creating valuable employment opportunities. In fact, after livestock production, the trade in khat could very well be the primary private employer in Somaliland. Apart from the thousands of drivers, porters, wholesalers and retailers that are directly engaged in the transport and trade in khat, there are also thousands of individuals who provide for themselves and their families by selling water, cigarettes, tea and sodas which accompany a usual chewing session. When discussing the issue of khat with local politicians, it was often made clear to me that the khat trade employed thousands of people, and that a potential reduction of khat consumption would not only have positive effects, but also cause unemployment and lost livelihoods. Based on own observations and interviews it is my estimate that around 7500 people are engaged in the transport of khat from Ethiopia to Somaliland. Added to this figure are the thousands of urban women who work as retailers of khat (cf. WSP International, 2005:27).

In the eyes of politicians, khat naturally also raises concerns. However, these concerns are most often not about bringing down consumption, but simply about organising the trade in and distribution of khat more efficiently. Often the arrival of khat creates traffic jams in urban centres when people rush to the market to get their daily bundles, and the plastic bags used for transporting khat from the retailer to the chewing session can be found hanging in trees and littering the streets. Moreover, the leftover khat stems are found all over town and often consumed by goats with the effect of influencing their health and potentially the health of babies when they are fed goat milk. Therefore, to politicians, khat represents a problem for urban planners, rather than an economic problem. One mayor explained to me that he had considered moving the khat market to the outskirts of town. However, the idea had been dropped as relocating the market would entail the relocation of the whole city centre with numerous businesses and activities being directly linked to the khat market.

Whereas it is mostly men that transport khat across the Ethiopian-Somaliland border and work as wholesalers, it is almost exclusively women who work as retailers of khat (cf. Warsame, 2004:125). In Hargeisa alone, it is my estimate that around 800 women provide for themselves and their families as retailers of khat. Profits at the retail level vary from around US\$ 4 to US\$20 per day all depending on the number of customers, the quality and price of the khat being sold, and on the distance from the central khat market. In general, khat selling women are stigmatised for engaging in an activity deemed unsuitable for women. However, these women often have no alternative livelihoods, being war widows or internally displaced persons without the support of extended families. Therefore they often feel that they are forced to enter a 
business that initially looks promising and with good returns, but often turns out to have a lot of negative effects. For example, they are concerned that they have to spend most of the day away from their children, as selling khat takes place as soon as the khat arrives until late in the evening. Also, when customers fail to pay for their khat, retailers are unable to pay wholesalers and often end up on in khat-trap where they are dependent on the good will of wholesalers and essentially unable to exit the khat business. However, most female khat retailers see khat as an opportunity, and they are known to do whatever it takes to feed their children. Some also believe that selling khat is a good learning experience and refer to it as attending "khat college".

The reason that men are not involved as traders at the retail level is related to a number of factors. First of all, men argue that it is not suitable for a man to spend the whole day selling khat for a rather low profit, whereas selling khat at the wholesale level is more respectable, as profits are known to be considerable higher. Wholesalers at the market in Hargeisa usually have a $10 \%$ profit margin, and usually make daily profits at around US\$ 50 and US\$ 100. Secondly, men argue that as they are often heavy consumers of khat they would end up consuming what they were supposed to sell. Thirdly, they argue that they would end up handing out khat for free to all their friends and relatives, as the sharing of resources among males (saxad ku nool) is seen as integral to Somali cultural values and practises.

\subsection{Khat and politics}

Khat is often presented as being linked to the disintegration of Somalia, and as a challenge to the further transformation of Somaliland as a political entity. For example, the fact that public institutions close in the afternoon, as chewers are busy with their khat, that government employees are often heavy consumers of khat and therefore more easily corruptible with bundles of khat, and that police officers often harass the public in order to get money for khat are often mentioned as examples of the negative impact khat has on the process of state-building in Somaliland. Moreover, consumers of khat are said to only care about the next bundle of khat which seriously challenges the more long-term development plans of the country. These arguments are all valid, but only represent one side of the coin. More than simply being a challenge to the political life of Somaliland, khat is an integral part of its political success. Already in the early 1990s, rather than leading to violence and war, khat played a crucial role in the negotiation of peace as it provided a known and appreciated space for opponents and enemies to meet and discuss their problems (cf. Walls, 2009). Often I have been told that Somaliland is peaceful because of khat, at is makes people relax and that without it, the country would return to civil war and anarchy. Even today, khat is important as it continues to be deeply integrated into everyday political practices.

The role of khat in politics is first and foremost seen in the consumption of khat by politicians, and in the use of khat when negotiating political deals between members of the government or opposition. The importance of the political mafresh or chewing session that takes place in the afternoon after the closure of formal political institutions has grown within the past decade (Ducaale, 2005:149). In Somaliland they say that "the meetings of the night are more important than the meetings of the day" indicating that political khat sessions are more important than the political meetings, debates and negotiations taking place in parliament and in the House of Elders. ${ }^{10}$ The fact that informal negotiations are important to the political life of Somaliland, is of course not something unique,

$\overline{10}$ Personal correspondence with Matt Bryden, Hargeisa, January 2006. but can be found in most African countries (Chabal and Daloz, 1989:95), and indeed in most countries around the world. What is remarkable in Somaliland is the extent to which the informal political space of the chewing session has been institutionalised, thereby blurring the boundaries between formal and informal political domains. For example, both the government and the opposition are known to establish their own chewing sessions whereby they seek to influence public opinion and to secure political support and votes.

The importance of khat goes beyond the political chewing sessions where politicians meet and discuss politics, as every chewing session inevitably touch upon political issues. Chewing sessions thereby represent important local forms of political participation, and are referred to by chewers themselves as "grassroots democracy”, “everyday forms of democracy”, "political workshops" and "peace dialogues" (cf. Cabdi, 2005:300). The chewing session thereby secures a flat or egalitarian political space where chewers feel that they are always part of whatever political issue is being discussed, and where they are often able to network decision makers via the chewing session. However, as a result of the war there has been a tendency for chewers to meet on the basis of clan membership making the mafresh a "hothouse of clan politics" (Ducaale, 2005:150). In this sense, khat has reinforced the importance of clan identities and clan based networks which challenge the formation of a citizenry that first and foremost sees itself as being responsible towards Somaliland rather than towards the clan. Moreover, whereas khat builds trust and strengthens intra-clan relationships and identities, it simultaneously strains inter-clan relationships with clan bashing and ridiculing being a favoured topic of most chewing sessions. However, with other chewing sessions being based on occupation, residency, profession or other socio-cultural principles, the consumption of khat does not necessarily reproduce or strengthen clan identities.

\section{Discussion}

\subsection{Khat and cultural ambiguities}

The status of khat in Somaliland is ambiguous in the sense that it both strengthens and challenges socio-cultural values, practices and identities. On the positive side, consumers first of all highlight that the experience of chewing and getting high (marqan) strengthen social ties and trust between fellow chewers, and a sense of belonging to Somaliland society. The social significance of khat is reinforced when consumers take turns buying and offering khat to fellow chewers. Usually, the better off bring their own khat to the chewing session, but for a group of less affluent consumers it is quite common to share whatever khat is available. Moreover, when invited for a special khat session, the host will usually pay for everything, including lunch, khat, sodas, tea, cigarettes, etc. In this sense, consumers of khat end up in multiple relations with obligations to give and opportunities to receive khat, relations of reciprocity and exchange that are important to the coherence of society (cf. Weir, 1985; Kennedy, 1987).

Secondly, consumers often argue that chewing khat has existential qualities, in the sense of focusing their attention on the here and now, on what takes place in the session and between chewers as a collective, rather than worrying about what tomorrow or the day after tomorrow will bring. A related argument is that khat enables consumers to endure a harsh life, as it is said to make people happy and to work as an anti-depressant. Consumers often stress that the reason why Somalis have been able to go through hell during the civil war without people committing suicide, is because of khat. Thirdly, there is a widespread understanding among consumers that all human beings need something to take their minds away 
from whatever problem they may be encountering, and that khat is simply less harmful than other substances such as alcohol, which is not only haram according to Islam, but also seen as a dangerous drug with various negative effects.

Finally, chewing khat is presented by consumers as an illustration of their love for democracy and pragmatism and in strong opposition to conservative Islamic classifications of khat as haram. Within the past decades, the influence of more purist and strict readings of the Quran have entered Somali society via Islamic movements and foreign jihadists who fight the Somali government and the African Union that are seen as infidels and stooges of the West (ICG, 2005; Menkhaus, 2007a,b; Møller, 2009; Norell, 2008). Among other things, the Islamists have argued that khat is haram, as it is a mind altering substance and has negative effects on the wellbeing of consumers and their families. The Islamic movements are most influential in South-central Somalia where they have taken control over most of the country and where they have simply banned khat. However, the influence of Islamic movements is also seen in Puntland where there are numerous Islamic schools that teach about the ills and evils of khat. In Somaliland, the consumption of khat is said to highlight their anti-fundamentalist interpretations of the Quran, and the marginal role of Islamic movements. In this sense, khat is used to distinguish Somaliland from Puntland and South-central Somalia, from where Somaliland tries to secure independence.

According to the most popular Somali interpretation, khat falls in the grey area between being haram and halal (i.e. makruh or mustabahat). With Islamists banning khat and classifying it as haram, the consumption of khat signals that Somalilanders are democrats rather than Islamic fundamentalist, and that they embody a more authentic Somali culture. When the British banned khat in British Somaliland in the 1950s, a similar process and politicisation of khat consumption also took place. Rather than lowering consumption, the ban on khat in pre-independence Somaliland simply turned the consumption of khat into an important symbol expressing nationalist and anti-colonial sentiments (Geshekter, 1985:27; Gebissa, 2004:82). Similarly, in parts of South-central Somalia the ban on khat is not popular among consumers, khat importers and those making a living off khat. The dissatisfaction with the Islamists and their classification of khat as haram has led to anti-khat-ban demonstrations in Baidoa in South-central Somalia, March 2009 (Ahmed and Guled, 2009; Duhul, 2009).

However, apart from these positive connotations and aspects, the consumption of khat also seriously challenges socio-cultural identities. Consumers are often presented by critics of khat as having lost their culture and morality, and being similar to goats who also spend most of the day chewing, and as such closer to nature, only responding to instincts and cravings of the body. Critics of khat argue that consumers loose control and behave outside Somali cultural norms and point to an increase in crime and adultery as proof (cf. Cabdi, 2005:303). ${ }^{11}$ Critics also point to the consumption of "blood khat" - khat that has been involved in a traffic accident on its way from Ethiopia to Somaliland - to illustrate how khat challenges the boundaries for what is normal and abnormal, and for what is shameful and honourable. Khat is also said to affect customary law which can be seen as representing the backbone of Somali culture and tradition. When elders and traditional authorities chew khat, and as such are potentially corruptible with khat, their status as guardians and judges of Somali cultural issues is seriously challenged. The consumption of khat by a growing number

\footnotetext{
11 According to the secretary of the Puntland Court in Garowe, approximately 20\% of all court cases relate to khat consumption (Hansen, 2006). Apparently, this figure is higher in Gabiley district in Somaliland, where it is reported that out of 99 civil cases in 1999, 67 of them were related to khat (Cabdi, 2005:303).
}

of nomads also seriously challenges rural Somali cultural identities. The nomad and the camel, as well as camel milk, are crucial in Somali cultural identities (Abdullahi, 2001). The camel is praised in poetry (Abokor, 1986) and most urban males tell stories of how they have been sent off to live with nomadic relatives, and how they only lived on camel milk in order to become real tough Somali men. Moreover, the livestock sector is usually described as the backbone of the Somaliland economy. Therefore, when herders are more concerned with khat than with taking care of their animals and families, and when camel milk is used to purchase khat, notions of who the Somalilanders are, how they will go from being boys to being men, and how they will survive are challenged.

\subsection{Khat and gender}

The effects khat has on Somali cultural values most often relate to a change in gender roles and relations (cf. Ibrahim, 2004; Warsame, 2004; Cabdi, 2005). According to gender ideals, the husband should be the breadwinner and head of the family, and he should orient himself outside the household as the active, rhetorically and poetically skilled and strong decision-making agent, whereas women, on the contrary, should orient themselves inwards towards the household as the obedient and serving wife taking care of cleaning, washing, cooking and caring for the children (Kapteijns, 1995; Gardner and Bushra, 2004; Hansen, 2008). Despite the fact that these are ideals and as such constantly negotiated and rarely exist in practice (Kleist, 2008), it is fair to say that Somali society is heavily influenced by patriarchal values and principles (Ahmed, 1995). Circumcision is one of the most important rituals for the creation of Somali gender categories and for gendering bodies (Helander, 1987; Talle, 1993) and referred to as xalaalays, stemming from the Arabic word halaal, meaning allowed or pure according to Islam. Circumcision is generally interpreted as an act of cleaning or of purification, making the girls more feminine in removing from the female body that which is seen as male and inherited from the father (Talle, 2003:41-42). Being clean (gari) is seen as a core female value, and a woman is expected to make sure that she and her children as well as the household are clean (Hansen, 2008). Similar to female circumcision, male circumcision can also be seen as a ritual of purification where the soft and feminine parts of the body are removed making men more like men (cf. Boddy, 1982). However, whereas male circumcision is essentially a ritual of exposure, female circumcision is a ritual of enclosure. This duality is reflected in the social position of men and women, with men expected to venture out in the public and to be strong, whereas women should be reserved, closed, and oriented inwards towards the household.

It is my argument that khat challenges these traditional gender categories. When chewers spend most of their income on khat away from their families, they fail as breadwinners and decision makers. Moreover, consumers of khat fail as men when they spend most of the day in the feminine space of private homes and khat cafés. Khat also challenges male identity when it causes impotency and the involuntary loss of semen (spermatorrhoea) whereby men loose the ability to reproduce the Somali people. ${ }^{12}$ Moreover, the loss of masculinity is also seen in the widespread belief that consumers are weak, that they have lost their muscles, have bad teeth, and suffer from various diseases. Among chewers, the loss of potency and semen is also of great concern. Many chewers tell stories of how they have lost their semen when going to the toilet, and how they have been unable to satisfy their wives because of khat. ${ }^{13}$ However,

\footnotetext{
12 On spermatorrhoea caused by khat see Luqman and Danowski (1976), Halbach (1972), Granek et al. (1988) and Elmi (1983).

13 Consumers say that "when semen goes down the drain, so does your marriage".
} 
there are also consumers who argue that khat increases their sexual performance and that it is simply a matter of finding the right khat that goes well with your blood type in order prevent the negative and emphasise the positive effects. ${ }^{14}$

Whereas khat surely has transformed and seriously challenges the traditional role of men as potent breadwinners and tough decision makers, most concern is on the ways in which khat transforms women and their identities. Female khat retailers in particular have come to epitomise how khat and the war have changed traditional notions of what a Somali woman is and how she should behave (cf. Cabdi, 2005:300). First of all, rather than being inside the house, taking care of children and the chores of the household, female khat vendors are out in the public, and engage with male customers in order to make a living. They thereby violate the notion that women should be closed and private, especially towards unknown and unrelated males. Secondly, female khat vendors often get into arguments with their customers, something that is seen as unfitting for a woman. Moreover, when arguing with customers over unpaid khat bills, they often resort to a form of language that is seen as impure, thereby violating the important principle that a woman should be clean. Arguing with and shouting at men in public is simply not compatible with traditional norms for good behaviour for a Somali woman. The changed behaviour of female khat vendors is also of great concern to themselves, as they are afraid that their children will learn from them and apply the same language and behaviour. Thirdly, there is a widespread belief among both consumers and non-consumers, that female khat vendors are prostitutes (cf. Beckerleg, 2008:1174). The fact that most female khat vendors tend to be quite beautiful and often flirt with their customers in order to strengthen their business, no doubt adds to the concern that it is possible to get more than khat and tea from these women.

Under the assumption that women are essentially weak, people are often concerned that female khat vendors working in khat cafés are essentially out to get hold of a man, and that she will have sex or run away with the strongest male. Related to this is the concern over run-away marriages between a young female khat vendor and a young male customer, where the marriage takes place over night and without the consent and support of the extended families. Moreover, some argue that they will sell sex to the wholesalers in order to work off their debts and thereby to get out of the khat-trap. Finally, there is a widespread belief that there are actual khat brothels where you can be fed by a woman and have sex with her at the same time. In this sense, khat increases promiscuity which again is said to contribute to the spread of diseases such as HIV/AIDS.

\section{Conclusion}

In this article I have examined the role of khat in contemporary Somaliland society. Whereas many critics rightly point to the various negative effects of khat, this article highlights both negative and positive aspects thereby countering the portrayal of khat as synonymous with state failure and violence in Somalia. This is not to say that khat is necessarily a good thing, nor that it automatically contributes to state formation, as it has done in Somaliland. On the contrary, various state and non-state actors have fought for control over the lucrative khat trade, both before and after the eruption of violence in Mogadishu and South-central Somalia in 1991. Because of the huge profits involved, khat also contributed to the re-emergence of violence in Somaliland following the declaration of independence in 1991. For example, the violence that

\footnotetext{
14 Like consumers, medical research on the effects of khat on sexual behaviour is contradictory with some reports highlighting that khat works as an aphrodisiac and others that it leads to impotency (Feyissa and Kelly, 2008:1158).
}

erupted in and around Hargeisa in 1994 and 1995 did not only concern the control of the recently introduced Somaliland Shilling and the airport, but also the khat trade (cf. Bradbury, 2008:118). Moreover, and according to my informants, the eruption of violence in Puntland in 2001 not only represented a fight between two presidential candidates, but also a fight between two khat importers over the Puntland khat market, one selling and promoting Ethiopian khat and the other Kenyan khat. Similarly, warlords in South-central Somalia are known to have financed their militias on profits made on khat imports to Mogadishu (UNSC, 2003). Moreover, warlords are known to recruit and pay their fighters on the provision of khat, and are frequently described by my informants from Mogadishu as "druglords". Fighting for the control over the various airstrips surrounding Mogadishu has also been an important element in the continuation of the civil war in South-central Somalia. Khat is also linked to revenge killings (Gundel, 2006:24) and the marauding behaviour of youth gangs, known as mooryaan in South-central Somalia, deydey or budhcad in Somaliland and jiriir or manofay in Puntland, who secure money for khat by looting and banditry (cf. Bradbury, 1993:79; Ibrahim, 2004:49). ${ }^{15}$ In this sense, khat surely has played an important part in the eruption and continuation of violence and instability in various parts of Somalia.

However, one of the points of this article is that khat has also played a positive role in relation to politics and state-building in Somaliland. Khat was important in the negotiation of peace in the early 1990s, it has created a trusted and participatory environment for doing politics and it has provided an important resource base for the emerging institutions of the state. However, when comparing Somaliland with other parts of Somalia that are still troubled by violence and where khat is also widely consumed, it is clear that it alone does not explain these various political trajectories. One important explanation as to why Somaliland is peaceful and South-central Somalia still troubled by violence, is that Somaliland is the result of the victory of one clan, whereas various clans are still fighting for power and influence in South-central Somalia which makes it much more difficult to set up a viable political system and state institutions. Moreover, whereas a system of conflict mediation based on the clan system survived both colonialism and the Somali state in Somaliland, it has largely broken down in South-central Somalia. The existence of local forms of conflict mediation based on traditional clan authorities has been crucial in terms of setting up a political and administrative system in Somaliland (cf. Gundel, 2006; Renders, 2007). As such, the relative success of Somaliland is linked to a process of mediation and institution building that builds on local socio-cultural values and actors. On the contrary, various external actors have engaged themselves in South-central Somalia making it difficult to set up viable and legitimate political institutions (Møller, 2009). Therefore, it is not khat in itself, but the socio-political context in which it is consumed that determines its larger societal effects.

A nuanced analysis of the good and bad aspects of khat is not only closer to local empirical realities but also necessary in order to work with khat from a regulatory perspective. Rather than trying to eradicate and ban khat, something that has proven counter productive in the past and in other parts of Somalia, it is my argu-

\footnotetext{
15 The word deydey literally means "searching" and originates from the idea of "the lost ones" - i.e. those that have been separated from their parents during the civil war. In the early 1990s, the word took on a second meaning of "those who do the searching" - i.e. those who resorted to looting as a livelihood strategy (Bradbury, 1993:79). In the early 1990s and before their demobilisation, they were also referred to as malin dagal, meaning "million a day", connoting that they need a million shillings per day in order to pay for ammunition, women and khat (Bradbury, 1993). The word jiriir is the name of a bird, and mooryaan means those who "smoke marijuana" (Bradbury, 1993:108).
} 
ment that khat should be treated as a substance that has been with Somalis for centuries, and is most likely to also play a part in their futures. As such a primary challenge for the international community and local politicians in Somaliland interested in regulating the consumption of khat is not to stigmatise and antagonise consumers. Most often the critique of khat is seen as being spearheaded as outside intervention and thereby as illegitimate. Rather than working against khat, it would be a more sound response to ensure that khat remains a legal substance whereby taxation and control are secured. The key to a long-term reduction of khat in Somaliland lies with the youth and is a long-term struggle of establishing better and more alternatives, employment opportunities and futures. Moreover, when working with khat as a developmental problem, it is important to keep in mind that the growth in khat consumption in Somalia was linked to infrastructural developments, urbanization and an increase in disposable income. As such, the consumption of khat both reflects a well-established tradition, societal changes and developments.

\section{References}

Abdullahi, M.D., 2001. Culture and Customs of Somalia. Greenwood Press, Westport, Connecticut/London.

Abokor, A.C., 1986. The Camel in Somali Oral Traditions. Nordic Africa Institute, Uppsala, Sweden.

Ahmed, C.C., 1995. Finely etched chattel: the invention of a Somali woman. In: Ahmed, A.J. (Ed.), The Invention of Somalia. The Red Sea Press, Lawrenceville, NJ, pp. $157-190$

Ahmed, M., 2005. Tower Hamlets Somali Population: Research into Substance Use/misuse. Community Organization Forum, London.

Ahmed, M., Guled, A., 2009. Somalis protest against al Shabaab's drug ban. Reuters. (Accessed at: http://www.reuters.com/article/idUSLP972817 on 14.01.2010).

Anderson, D.M., Carrier, N., 2006. Flowers of paradise, or polluting the Nation? Contested Narratives of Khat Consumption. In: Brewer, J., Trentmann, F. (Eds.), Consuming Cultures, Global Perspectives: Historical Trajectories, Transnational Exchanges. Oxford, Berg, pp. 145-166.

Anderson, D., Beckerleg, S., Hailu, D., Klein, A., 2007. The Khat Controversy. Stimulating the Debate on Drugs. Oxford, Berg.

Beckerleg, S., 2008. Khat in East Africa: taking women into or out of sex work? Substance Use and \& Misuse 43, 1170-1185.

Bestemann, C., 1999. Unraveling Somalia: race. In: Violence and the Legacy of Slavery. University of Pennsylvania Press, Philadelphia.

Boddy, J., 1982. Womb as oasis: the symbolic context of pharaonic circumcision in rural Northern Sudan. American Ethnologist 9, 682-698.

Bradbury, M., 1993. The Somali Conflict: Prospects for Peace. Oxfam Research Paper no. 9. Oxford, Oxfam, UK/Ireland.

Bradbury, M., 2008. Becoming Somaliland. Progressio/James Currey, London.

Bradbury, M., Abokor, A.Y., Yusuf, H.A., 2003. Somaliland: choosing politics over violence. Review of African Political Economy 97, 455-478.

Cabdi, S.I., 2005. The Impact of the War on the Family, in Rebuilding Somaliland. Issues and possibilities, WSP International. The Red Sea Press, Lawrenceville, pp. 269-325.

Cassanelli, L.V., 1986. Qat: changes in the production and consumption of a quasilegal commodity in northeast Africa. In: Appadurai, A. (Ed.), The Social Life of Things. Commodities in Cultural Perspective. Cambridge University Press, Cambridge, pp. 236-257.

Chabal, P., Daloz, J.-P., 1989. Africa Works. Disorder as Political Instrument. James Currey, Oxford.

Cox, G., Rampes, R., 2003. Adverse effects of khat: a review. Advanced Psychiatric Treatment 9, 456-463.

Davies, C.A., 1999. Reflexive Ethnography. A Guide to Researching Selves and Others. Routledge, London/New York.

DeWalt, K.M., DeWalt, B.R., 2002. Participant Observation. A Guide for Fieldworkers. Altamira Press, Walnut Creek.

Dhaifalah, I., Santavy, J., 2004. Khat habits and its health effects. a natural amphetamine. Biomedical Papers 148, 11-15.

Doornbos, M., 2002. Somalia: alternative scenarios for political reconstruction. Africa Affairs 101, 93-107.

Ducaale, B.Y., 2005. The Role of the Media in Political Reconstruction, in Rebuilding Somaliland. Issues and Possibilities. The Red Sea Press, Lawrenceville \& Asmara, pp. 123-188.

Duhul, S., 2009. Witnesses: Somalis protest Islamist drug ban. Associated Press (Accessed at http://berthoalain.wordpress.com/2009/03/26/violence-a-baidoamars-2009/ on 12.01.2010).

Elmi, A.S., 1983. The chewing of khat in Somalia. Journal of Ethnopharmacology 8, 163-176.

Feyissa, A.M., Kelly, J.P., 2008. A review of the neuropharmacological properties of khat. Progress in Neuro-Psychopharmacology \& Biological Psychiatry 32, 1147-1166.
Gardner, J., Bushra, J.E., 2004. Introduction. In: Gardner, J., Bushra, J.E. (Eds.), Somalia-The Untold Story. The War Through the Eyes of Somali Women. Pluto Press, London, pp. 1-23.

Gebissa, E., 2004. Leaf of Allah. Khat \& Agricultural Transformation in Harerge, Ethiopia 1875-1991. James Currey, Oxford.

Geshekter, C.L., 1985. Anti-colonialism and class formation: the Eastern Horn of Africa before 1950. The International Journal of African Historical Studies 18, $1-32$.

Granek, M., Shalev, A., Weingarten, A.M., 1988. Khat-induced hypnagogic hallucinations. Acta Psychiatrica Scandinavica 78, 458-461.

Green, R.H., 1999. Khattt \& the realities of Somalis: historic, social, household, political \& economic. Review of African Political Economy 79, 33-49.

Gundel, J., 2006. The predicament of the 'Oday'. The role of traditional structures in security, rights, law and development in Somalia. Final Report. Danish Refugee Council \& Novib-Oxfam, Nairobi.

Hagmann, T., Hoehne, M.V., 2009. Failures of the state failure debate: evidence from the Somali Territories. Journal of International Development 21, 42-57.

Halbach, H., 1972. Medical aspects of the chewing of khat leaves. Bulletin of the World Health Organization 47, 21-29.

Hansen, P., 2004. Migrant Transfers as a Development Tool. The Case of Somaliland. DIIS Working Paper no. 15. Danish Institute for International Studies, Copenhagen.

Hansen, P., 2006. Khat Sub-cluster Report. UNDP Somalia/The World Bank, Joint Needs Assessment for Somalia, Nairobi.

Hansen, P., 2007a. Revolving returnees in Somaliland. In: Sørensen, N.N. (Ed.), Living Across Worlds: Diaspora, Development and Transnational Engagement. International Organization for Migration (IOM), Geneva, pp. 129-150.

Hansen, P., 2007b. Revolving Returnees. Meanings and Practices of Transnational Return among Somalilanders. Ph. D. Dissertation. Department of Anthropology, Copenhagen.

Hansen, P. 2008. Circumcising migration. Gendering return migration among Somalilanders. Journal of Ethnic and Migration Studies 34, 1109-1125.

Helander, B., 1987. Gender and Gender Characteristics as a Folk Model in Southern Somali Social Classification and Symbolism. Department of Cultural Anthropology, Uppsala.

Hoehne, M.V., 2006. Political identity, emerging state structures and conflict in northern Somalia. Journal of Modern African Studies 44, 397-414.

Hoehne, M.V., 2009. Mimesis and mimicry in dynamics of state and identity formation in Northern Somalia. Africa 79, 252-281.

Holy, L., Stuchlik, M., 1983. Actions, Norms and Representations: Foundations of Anthropological Inquiry. Cambridge University Press, Cambridge.

Ibrahim, R.M., 2004. Women's role in the pastoral economy. In: Gardner, J., Bushra, J.E. (Eds.), Somalia-The Untold Story. The War Through the Eyes of Somali Women. Pluto Press, London, pp. 24-50.

ICG, 2005. Somalia's Islamists. Africa Report No. 100. International Crisis Group, Nairobi/Brussels.

Kapteijns, L., 1995. Gender relations and the transformation of the Northern Somali pastoral tradition. International Journal of African Historical Studies 28, 241-259.

Kennedy, J.G., 1987. The Flower of Paradise: The Institutionalized Use of the Drug Qat in North Yemen. Reidl, Dordrecht.

Klein, A., 2004. Khat in Streatham: Formulating a Community Response. Streatham Town Centre Office, London.

Klein, A., 2007. Khat and the creation of tradition in the Somali diaspora. In: Fountain, J., Korf, D.J. (Eds.), Drugs in Society. European Perspectives. Radcliffe Publishing, Oxon, pp. 51-61.

Kleist, N., 2008. Mobilising 'The Diaspora': Somali transnational political engagement. Journal of Ethnic and Migration Studies 34, 307-323.

Lewis, I.M., 1994. Blood and Bone. The Call of Kinship in Somali Society. The Red Sea Press, Lawrenceville.

Lewis, I.M., 2002. A Modern History of the Somali. Nation and State in the Horn of Africa. James Currey, Oxford.

Lindley, A., 2006. Migrant Remittances in the Context of Crisis in Somali Society. A Case Study of Hargeisa. Overseas Development Institute, London.

Little, P.D., 2003. Somalia: Economy Without State. James Currey, Oxford.

Luqman, W., Danowski, T.S., 1976. The use of khat (Catha edulis) in Yemen. Soocial and medical observations. Annals of Internal Medicine 85, 246-249.

Menkhaus, K., 2007a. The crisis in Somalia: tragedy in five acts. African Affairs 106 357-390.

Menkhaus, K., 2007b. Governance without Government in Somalia. Spoilers, state building, and the politics of coping. International Security 31, 74-106.

Møller, B., 2009. The Somali Conflict. The Role of External Actors. DIIS Report 2009:03. Danish Institute for International Studies, Copenhagen.

Norell, M., 2008. Islamist Networks in Somalia. FOI Somalia Papers: Report 2. Swedish Defence Research Agency, Defence Analysis, Stockholm.

Odenwald, M., et al., 2009. The stimulant khat-another door in the Wall? A call for overcoming the Barriers. Journal of Ethnopharmacology. doi:10.1016/j.jep.2009.11.005.

Renders, M., 2007. Appropriate 'governance-technology'? Somali clan elders and institutions in the making of the 'Republic of Somaliland'. Afrika Spectrum 42, 439-459.

Samatar, A.I., 1985 . The predatory state and the peasantry: reflections on rural development policy in Somalia. Africa Today 32, 41-56.

Samatar, A.I., 1989. The State and Rural Transformation in Northern Somalia 1884-1986. The University of Wisconsin Press, Madison. 
Simons, A., 1995. Networks of Dissolution. Somalia Undone. Westview Press, Colorado.

Somaliland Times, 2009. Suhuura Airways Opens Its Doors in Somaliland. Somaliland Times, Hargeisa, Somaliland.

Talle, A., 1993. Transforming women into 'Pure' agnates: aspects of female infibulation in Somalia. In: Broch-Due, V., Rudie, I., Bleie, T. (Eds.), Carved Flesh Cast Selves. Gendered Symbols and Social Practice. Berg Publishers, Oxford, pp. 83-106.

Talle, A., 2003. Om kvinneleg omskjering. Debatt og erfaring. Det Norske Samlaget, Oslo.

UNSC, 2003. Report of the Panel of Experts on Somalia pursuant to Security Council resolution 1425 (2002). United Nations Security Council, New York.
Walls, M., 2009. The emergence of a Somali state: building peace from civil war in Somaliland. African Affairs 108, 371-389.

Warsame, A.M., 2004. Crisis or opportunity? Somali women traders and the war. In: Gardner, J., Bushra, J.E. (Eds.), Somalia-The Untold Story. The War Through the Eyes of Somali Women. Pluto Press, London, pp. 116-126.

Weir, S., 1985. Qat in Yemen: Consumption and Social Change. The Trustee of the British Museum, London.

WHO, 1983. Report of the WHO Intercountry Meeting on the Health, Social and Economic Aspects of Khat. Mogadishu, 24-28 October 1983. World Health Organization, Geneva.

WSP International, 2005. Rebuilding Somaliland. Issues and Possibilities. The Red Sea Press, Lawrenceville/Asmara. 